\title{
COOKING CLASS SEBAGAI PAKET WISATA DI RESTORAN LAKA LEKE UBUD BALI
}

\author{
M. Rizky Nugraha S. \\ I Made Sendra \\ Ni Putu Eka Mahadewi \\ Email : surbaktirizky45@gmail.com \\ PS. S1 Industri Perjalanan Wisata \\ Fakultas Pariwisata UNUD
}

\begin{abstract}
Selection of research on "Cooking Class as Tour Packages at the Restaurant Laka Leke in Ubud Bali" is motivated the potential that cant be find anything in Ubud area which can be put into a package "cooking class", and how to plan a tour package "cooking class" in support of the potential that exists in Ubud. Data collection in this study was done by observation, interviews, and library research. Type of data used is the qualitative data supported by quantitative data, while the data source are the primary data and secondary data.

Results of this study showed that of the observations made on potentiality of tourism in Ubud village is still a lot of potentials that has not been developed and the maximum attention, especially from the local government. Development of tourism in Ubud village just focus on a few places in the Ubud area.

For the Bureau of Tourist's Travel or restaurant should pay more attention to making travel packages which involving local communities and make a package that is unique and different so will not appear tour packages that already exist.
\end{abstract}

Keywords: Package, Cooking Class, and Ubud.

\section{PENDAHULUAN}

Pariwisata yang sedang berkembang di Indonesia saat ini adalah pariwisata budaya. Tujuannya untuk melestarikan kebudayaan dan kepribadian bangsa. Dasar pemikirannya adalah bila suatu negara memiliki keindahan alam yang sama, fasilitas, sarana dan prasarana yang sama pula. Tidak hanya pantai yang bersih, udara yang segar, tempat-tempat rekreasi yang menarik tetapi untuk memenangkan persaingan harus memiliki nilai plus bagi wisatawan yang hendak berkunjung ke Indonesia. Nilai plus itu tidak lain adalah seni budaya tradisional itu sendiri yang perlu dikelola, dikembangkan, dan dilestarikan sebagai atraksi wisata yang menarik dalam menunjang kepaiwisataan.
Bali merupakan salah satu daerah tujuan wisata di Indonesia. Pariwisata yang berkembang dan menjadi ciri khas dari Bali adalah Pariwisata Budaya.Banyak potensi budaya yang dapat dikembangkan menjadi daya tarik wisata.Pertumbuhan dan perkembangan pembangunan kepariwisataan yang telah dicapai oleh pemerintah Bali dapat dilihat dengan adanya peningkatan kunjungan wisatawan setiap tahunnya.Hal ini mendorong munculnya jenis pariwisata baru di pulau Bali, ditengah jenuhnya wisatawan dengan jenis wisata yang tidak memiliki keragaman.

Keragaman jenis wisata bisa jadi merupakan variabel pokok yang menjadi daya tarik utama bagi calon wisatawan. Kejenuhan akan rutinitas hidup sehari - hari, tuntutan waktu 
yang terbatas, serta pertimbangan efisiensi ekonomi membuat calon - calon wisatawan tersebut berusaha mencari produk - produk wisata altenatif, yang mampu memenuhi hasrat akan kepuasan, kenyamanan, petualangan, rekreasi, memperbanyak pengalaman baru, dan tentu saja mudah, murah, dan praktis.

Salah satu produk wisata alternatif yang cukup digemari saat ini adalah atraksi wisata minat khusus. Sesuai dengan Undang-Undang Nomor 9 tahun 1990, pengertian wisata minat khusus yang tercakup disini adalah "wisata yang memanfaatkan sumberdaya alam dan potensi seni budaya bangsa untuk menimbulkan daya tarik dan minatkhusus sebagai sasaran wisata". Wisata minat khusus tersebut dapat berupa kegiatan - kegiatan olahraga di alam bebas, seperti arung jeram, panjat tebing, mountain hiking, dan sebagainya.

Wisata minat khusus yang menarik saat ini adalah wisata kuliner. Wisata kuliner memiliki keunggulan tersendiri terutama dalam masakan tradisional, hal ini dapat dibuktikan dengan pengolahan bahan segar dan alami, tidak menggunakan zat adiktif, sesuai dengan selera dan kebiasaan, biaya relatif murah dan bervariasi.

Ubud merupakan salah satu daerah di Bali yang menyimpan banyak potensi wisata yang dapat dikembangkan sebagai daya tarik wisata. Ubud memiliki banyak objek wisata yang menarik untuk mengisi liburan wisatawan yang berkunjung ke bali. Seperti yoga di pagi hari, naik sepeda di tepi sawah, mengunjungi museum, wisata kuliner, belajar memasak makanan khas bali dan masih banyak lagi.

Restoran Laka Leke merupakan salah satu restoran di Ubud yang menawarkan paket "cooking class" ke wisatawan yng berkunjung ke Bali, khususnya Ubud. Dimana paket wisata "cooking class" yang ditawarkan Restoran Laka Leke untuk mengajarkan wisatawan memasak masakan tradisional Bali.

\section{TINJAUAN PUSTAKA}

Penelitian yang dilakukan Elistyawati (2011) yang meneliti tentang " Modifikasi Makanan Tradisional Berbahan Dasar Bebek sebagai Pendukung Industri Pariwisata di Ubud". Penelitian ini bertujuan untuk mengembangkan produk makanan berbahan dasar bebek, baik dari segi bumbu, proses pengolahan, rasa, penyajian dan variasi menu yang berbahan dasar bebek.

Penelitian yang dilakukan Simon (2010) yang meneliti tentang "Exploring Marketing Strategy of Culinary Tourism Development and in Hongkong and Singapore". Penelitian ini bertujuan untuk pembangunan wisata kuliner dan menganalisis kerangka untuk mengembangkan wisata kuliner.

Menurut Nyoman S. Pendit (1994) dalam buku " Ilmu Pariwisata Sebuah Pengantar Perdana" menyebutkan potensi wisata adalah " segala sesuatu yang ada di suatu daerah yang dapat dikembangkan menjadi daya tarik wisata”.

Fandeli (2002) menyatakan pariwisata minat khusus diterjemahkan dari special interest tourism.Bentuk wisata ini apabila dilihat dari wisatawannya merupakan pariwisata dengan wisatawan dengan kelompok atau rombongan kecil.

Yoeti (2003) mengartikan paket wisata adalah setiap perjalanan yang dipublikasikan atau perjalanan yang dilakukan ke satu daya tarik wisata yang meliputi pelayanan transportasi, akomodasi dan faktor-faktor yang mendukung kegiatan perjalanan.

Menurut Yoeti (1996) Pariwisata adalah suatu perjalanan yang dilakukan untuk sementara waktu yang diselenggarakan dari tempat satu ke tempat lain dengan maksud bukan untuk bekerja di tempat yang dikunjungi tapi semata-mata untuk menikmati perjalanan guna untuk bertamasya dan berekreasi.

Menurut Spillane (1987) dalam bukunya Pariwisata Indonesia memberi batasan pariwisata yaitu suatu perjalanan dari satu tempat ke tempat lain yang bersifat sementara, dilakuakan perseorangan maupun kelompok, sebagai usaha mencari keseimbangan, keserasian dan kebahagiaan dalam lingkungan hidup dalam dimensi sosial, budaya, alam, dan ilmu.

Dalam buku karangan Ariani (1994) yang berjudul Seni Kuliner bali mengungkapkan tentang ketertarikan wisatawan mengenai masakan tradisional. Masakan tradisional terbukti memberikan daya tarik tersendiri bagi wisatawan nusantara dan mancanegara. 


\section{METODE PENELITIAN}

Penelitian ini dilakukan di daerah Ubud dengan fokus penelitian paket wisata yang ditawarkan Restoran Laka Leke. Pemelihan restoran tersebut sebagai tempat penelitian dikarenakan restoran tersebut menyediakan paket wisata cooking class. Metode penelitian ini menggunakan metode pengumpulan data kualitatif, dengan melakukan observasi, wawancara mendalam dan studi kepustakaan.

Dalam mendapatkan informasi yang lengkap penelitian ini memilih calon informan yang tepat dan sesuai dengan bidang yang akan diteliti. Untuk itu dilakukan wawancara mendalam kepada asisten manajer dan kitchen manager. Mereka adalah orang-orang yang mengerti dan mengetahui bidang yang akan diteliti di Restoran Laka Leke.

Analisis yang digunakan adalah analisis deskriptif kualitatif, yaitu dengan melakukan observasi, wawancara dan dianalisis. Analisis dimaksudkan untuk mengidentitifikasi kendala yang mungkin timbul dalam proses pencapain tujuan dan mencari alternatif-alternatif yang mungkin dapat ditempuh.

\section{HASIL DAN PEMBAHASAN}

Peraturan pemerintah Provinsi Bali No 3 Tahun 2005 tentang Rencana Tata Ruang Wilayah Provinsi Bali, menyebutkan bahwa kawasan pariwisata Ubud merupakan salah satu dari 15 kawasan pariwisata. Kawasan pariwisata Ubud ini berdasarkan Rencana Induk Pengembangan Pariwisata Daerah Bali ( RIPPDA Bali) tahun 2006 yang terdiri atas 13 desa yang tersebar di 3 Kecamatan Ubud, Payangan dan Tegelalang.

Secara umum potensi yang dimiliki ketiga kecematan ini meliputi: pertanian dalam arti luas, industry kerajinan dan pariwisata. Khusus untuk sektor pariwisata perkembangan kawasan Ubud sebagai sebuah kawasan pariwisata didukung oleh potensi topografi wilayah dan tradisi sosial budaya masyarakat. (Dinas Pariwisata Kabupaten Gianyar, 2011).

Penduduk Kelurahan Ubud memiliki beragam usaha dan mata pencaharian dalam menunjang kelangsungan hidupnya. Berdasarkan data dari profil pembangunan kelurahan Ubud, mata pencaharian penduduk Kelurahan Ubud sangatlah beragam. Bidang usaha yang paling tinggi adalah petani dengan jumlah 663 orang $(29,07 \%)$. (Dinas Pariwisata Kabupaten Gianyar, 2011)

\section{Potensi Wisata Cooking Class Di Ubud Bali Menjelajah Sawah}

Restoran Laka Leke memiliki luas 2 hektar dan memiliki area persawahan sebagai daya tarik bagi wisatawan yang datang. Sawah dimanfaatkan untuk mengajarkan kepada wisatawan cara bercocok tanam tanaman padi. dimana tanaman padi akan dibawa ke dapur restoran dan dimasak menjadi nasi. Nasi merupakan makanan pokok masyarakat Indonesia.

\section{Wisata Kebun}

Kebun yang dimiliki oleh restaurant Lakalake terdiri dari kebun yang hasilnya bisa dimanfaatkan untuk bumbu dapur. Banyak tanaman yang bisa dimanfaatkan seperti tomat, terong, cabai dan lain-lain.

\section{Cooking Class}

Dalam "cooking class" ini peserta akan diberitahu bahan-bahan yang akan digunakan dalam kegiatan memasak masakan tradisional. Setelah itu peserta akan diajarkan cara memasak masakan tradisional.

\section{Perencanaan Paket Wisata Cooking Class}

\section{Starting Point}

Titik awal adalah tempat/wilayah/daerah yang dijadikan awal pergerakan wisatawan untuk memulai tour.

2. Finishing point

Titik akhir adalah tempat dimana suatu tour diakhiri. Dalam laporan ini titik akhir ditentukan di kawasan Ubud.

3. Waktu tempuh antar objek wisata

Waktu tempuh disini harus dibedakan dengan waktu tempuh dalam balapan, hal ini dikarenakan dalam pariwisata ada usaha interpretasi berkelanjutan pramuwisata agar dapat memberi nilai tambah bagi wisatawan.

4. Durasi dalam menikmati objek wisata

Durasi menikmati objek dan atraksi wisata antara satu tempat dengan tempat lain sangatlah berbeda. Hal ini tergantung dari jenis luas dan tempat dan kemampuan 
pramuwisata menginterprestasikan daya tarik yang ada pada objek wisata.

\section{Perencanaan Paket Wisata "Cooking Class" Dalam Bentuk Uraian}

Perjalanan diawali pukul 03.30 menjemput peserta. Sampai direstoran pukul 04.00 peserta akan disambut dengan welcome drink. Selanjutnya menuju sawah dan disawah tersebut peserta akan mempelajari cara bercocok tanam padi, menumbuk benih, cara memanen. Selanjutnya peserta "cooking class" akan diajak menuju kebun disini peserta akan memetik sebagian bahan-bahan yang menjadi bumbu saat memasak nanti. Dari kebun menuju dapur dan didapur tersebut peserta akan diajarkan memasak masakan tradisional seperti masakan khas Bali, ayam betutu dan masakan khas Indonesia, seperti nasi goreng dan gado-gado. Selesai memasak peserta akan diberikan cendra mata berupa kaos. Selanjutnya peserta "cooking class" akan dibawa menuju restoran untuk menikmati hasil masakan mereka sendiri dan menikmati hiburan seni tari-tarian khas bali. Seperti, tari barong dan tari pendet.

Perencanaan Paket Wisata “Cooking Class” Dalam Bentuk Tabel Baris Kolom

\begin{tabular}{llcll}
\hline No & \multicolumn{1}{c}{$\begin{array}{c}\text { Tempat } \\
\text { Hari/Tanggal }\end{array}$} & Waktu & $\begin{array}{c}\text { Rencana } \\
\text { Perjalanan }\end{array}$ & Keterangan \\
\hline 1 & $\begin{array}{l}\text { Restoran Laka Leke } \\
\text { Ubud }\end{array}$ & 16.00 & $\begin{array}{l}\text { Kumpul di } \\
\text { restoran }\end{array}$ & Peserta akan menikmati "welcome drink" \\
& Sabtu 29/06/2013 & & &
\end{tabular}

\begin{tabular}{lcll}
\hline 2 & 16.10 & $\begin{array}{l}\text { Tiba di } \\
\text { persawahan }\end{array}$ & Peserta diajarkan cara bercocok tanam padi \\
\hline 3 & 16.45 & $\begin{array}{l}\text { Berangkat } \\
\text { menuju } \\
\text { kebun }\end{array}$ \\
\hline 4 & 16.55 & $\begin{array}{l}\text { Tiba di } \\
\text { perkebunan }\end{array}$ & $\begin{array}{l}\text { Peserta akan diajak memetik bahan-bahan untuk } \\
\text { memasak }\end{array}$ \\
\hline 5 & 17.30 & $\begin{array}{l}\text { Berangkat } \\
\text { menuju } \\
\text { dapur } \\
\text { restoran }\end{array}$ \\
\hline 6 & 17.40 & $\begin{array}{l}\text { Tiba di } \\
\text { dapur } \\
\text { restoran }\end{array}$ & Peserta akan diajarkan untuk memasak makanan \\
& & tradisional Bali \\
\hline 7 & 18.40 & $\begin{array}{l}\text { Berangkat } \\
\text { menuju } \\
\text { restoran }\end{array}$ \\
\hline 8 & 18.45 & $\begin{array}{l}\text { Tiba di } \\
\text { restoran }\end{array}$ & Menikmati masakan sambil melihat tarian \\
& traditional Bali \\
\hline 9 & 19.15 & $\begin{array}{l}\text { Peserta } \\
\text { kembali ke } \\
\text { hotel }\end{array}$ \\
\hline
\end{tabular}




\section{SIMPULAN DAN SARAN Simpulan}

1. Potensi Wisata di Ubud Bali

Seperti yang diuraikan pada bab sebelumnya bahwa Kabupaten Gianyar, khususnya Ubud memiliki berbagai macam potensi wisata. Seperti contohnya: persawahan, perkebunan dan atraksi wisata lain yang berada di sekitar restaurant Laka leke yang belum banyak diketahui banyak orang. Adapun seperti persawahan yang masih terjaga sehingga dapat dilakukan atraksi wisata seperti cara bercocok tanam dan cara memanen padi. Disamping itu ada galeri-galeri budaya dimana wisatawan dapat melihat hasil-hasil lukisan seniman Ubud dan wisatawan diajak belajar melukis diatas kanvas. Selanjutnya ada kegiatan "cooking class" yang dimana wisatawan akan diajarkan mulai dari memetik bahan-bahan untuk memasak.

2. Perencanaan Paket Wisata

Berdasarkan observasi yang telah dilakukan sebelumnya. Ubud memiliki potensi wisata yang beragam serta sangat baik untuk dijadikan sebagai daya tarik wisata. Oleh karena itu, perencanaan paket wisata yang dapat dibuat berdasarkan kepada potensipotensi yang ada seperti yang dicantumkan pada bab sebelumnya adalah Paket Wisata "Cooking Class" di Restoran Laka Leke Ubud Bali yang mengajarkan wisatawan memasak makanan tradisional Indonesia, khususnya Bali.

\section{Saran}

Berdasarkan banyaknya potensi-potensi wisata yang berada di Ubud hendaknya bagi BPW dan restoran membuat lebih meningkatkan pengembangan wisata dengan membuat paketpaket baru yang menarik dan unik khususnya di bidang kuliner, seperti paket wisata "cooking class" yang berguna untuk menarik wisatawan lokal maupun asing untuk berkunjung ke Ubud,Bali.

\section{DAFTAR PUSTAKA}

Ariani,R.P 1994. Studi Kelayakan Seni Kuliner Bali Mengenai Hidangan Tradisional Provinsi Bali : Laporan Penelitian,Singaraja:STKIP

Dinas Kabupaten Gianyar. 2011. Data Profil Pembangunan Ubud. Bali

Elistyawati. 2011. Modifikasi Makanan Tradisional Berbahan Dasar Bebek Sebagai Pendukung Industri Pariwisata di Ubud. Denpasar : Universitas Udayana

Fandeli,C. 2002. Perencanaan Kepariwisataan Alam. Yogyakarta : Fakultas Kehutanan Universitas Gajah mada

Pendit, S. Nyoman. 1994. Ilmu Pariwisata, Sebuah Pengantar Perdana. Jakarta : PT Pradnya Paramitha

Simon. 2010. Exploring Marketing Strategy Of Culinary Tourism Development in Hongkong and Singapore. Taiwan : National Taiwan Normal University

Spillane, J. 1987. Ekonomi Pariwisata, Sejarah dan Prospeknya. Yogyakarta : Kanisius.

Yoeti, A Oka. 1996. Pengantar Ilmu Pariwisata. Bandung : Angkasa 2003. Tour and Travel Marketing. Jakarta: Pradnya Paramitha. 